九州大学学術情報リポジトリ

Kyushu University Institutional Repository

\title{
Distribution of Houses Determined by Geomorphology, Landslides and People's Perception in Nallu Khola Watershed, Nepal
}

Joshi, jagannath

Laboratory of Soil and Water Conservation, Faculty of Agriculture, Kyushu University

Omura, Hiroshi

Laboratory of Soil and Water Conservation, Faculty of Agriculture, Kyushu University

https://doi.org/10.5109/24344

出版情報 : 九州大学大学院農学研究院紀要. 44 (3/4)，pp.431-443，2000-02. Kyushu University バージョン：

権利関係 : 


\title{
Distribution of Houses Determined by Geomorphology, Landslides and People's Perception in Nallu Khola Watershed, Nepal
}

\author{
Jagannath Joshi and Hiroshi Omura \\ Laboratory of Soil and Water Conservation, Faculty of Agriculture. \\ Kyushu University, Fukuoka 812-8581 Japan \\ (Received September $2 \pi, 1999$ and accepled Nonember 5, 1999)
}

\begin{abstract}
This study was carried oul to analyze the relationship among distribution of houses, geomorphological parameters, landslide distribution and people's perception in a middlc nountain watershed of Nepal. It focuses on the analysis of distribution of houses with respect to slope gradient, relief, elevalion, diraintage lrequency and landslide distribution. Stereo pairs of black and white aerial photographs, topographic: map and updated ficld data of house and landslide distribution were used for geonorphological analysis. I)ensity of houses with respect to slope, relief, elevation, drainage frequency and landslide density wore cstimated. A questionnaire survey was carried out to analyze peoples' perception regarding the landslide fazard around their residence. The study points out that the most preferred place for residence in the study area is gently sloping land around $10^{\circ}$ slope gradient, relicf about $20 \mathrm{~m}$, elevation between $1700-1800 \mathrm{~m}$ and least dissected by the drainage which is comparatively safe and convenient. However, $20 \%$ houses are built in high hazard area of shallow landslides, mainly due to increased population, poor economic condition and lack of alternative safe place for residence. Majority of the inhabitants have stated that they are aware of landslide hazard around their residence, but they are not ready to migrate out side.
\end{abstract}

\section{INTRODUCTION}

Considerable human lives and property are exposed to the risk of widespread landslides occurring at increasingly shorter intervals (Daluwatta et al., 1994). So, there is a greater need for study of human settlements in relation to their geophysical setting. Understanding the relationship among geomorphological characteristics of a watershed, common natural hazards like landslides and people's perception regarding natural hazards around their residence is of prime importance for disaster prevention planning and implementation of development schemes. In the case of human dominated fragile landscapes, a study of these aspects will certainly help to plan and implement any development program. Identification of critical areas and formulation of plan based on socioeconomic condition, status of natural resources and geophysical or geomorphological setting of the watershed are basic requircments for landslide or debris flow disaster prevention program. Since shallow or deep seated landslides are the most common natural hazards in Nepal, causing 300-400hundred people's death each year including destruction of houses and other properties (Sharma 1988, MOH 1994), a study of distribution of houses in relation to geomorphological parameters, shallow landslide distribution and pcople's perception regarding the landslide hazard around their residence is carried out in a middle mountain watershed of Nepal.

The objectives of this study are: 1) to find out relationship between genmorphological characteristics of the watershed and distribution of dwellers' houses; and 2) to study the 
peoples' perception regarding landslide hazard around their residence.

\section{STLDY AREA}

This study is carried out in Nallu Khola watershed, which lies between $27^{\circ} 32^{\prime} \mathrm{N}$ and $27^{\circ} 34^{\prime} \mathrm{N}$ latitude and between $85^{\circ} 19^{\prime} \mathrm{E}$ and $85^{\circ} 25^{\prime} \mathrm{E}$ longitude (Figure 1). The study area $\left(16.04 \mathrm{~km}^{2}\right)$ is located in Lalitpur district of Nepal, about $19 \mathrm{~km}$ south of Kathmandu valley. General and geomorphological characteristics of the watershed are shown in Table 1. Four major types of land use exist in the study area. These land use types are: 1) cultivated land, 2) forest, 3) shrub land, and 4) other. Cultivated land occupies 44 percent of total watershed area. It includes sloping terraces and the land used to produce fodder for cattle, locally called as "Kharbari". Forests are distributed through out the watershed and occupy 40 percent of total area. These forests can be classified into three types: pine forest, broad-leaved forest, and mixed forest. Pine forest is of mainly plantation forest that exists in the southern aspects of the study area below $2,000 \mathrm{~m}$. Natural broad-leaved forest exists mainly in the northern aspects and mixed forest of pines and broad-leaf tree species exists in the transitional areas. Other land use type includes debris deposited areas along the streamside and bare land. Shrub land and other land use type occupy 15 and 1 percent of total watershed area respectively.

Climate of the study area is sub-tropical $(<2000 \mathrm{~m})$ to lower temperate $(2000-$ $2625 \mathrm{~m}$ ). The mean annual rainfall is $1889 \mathrm{~mm}$ estimated at the nearest meteorological

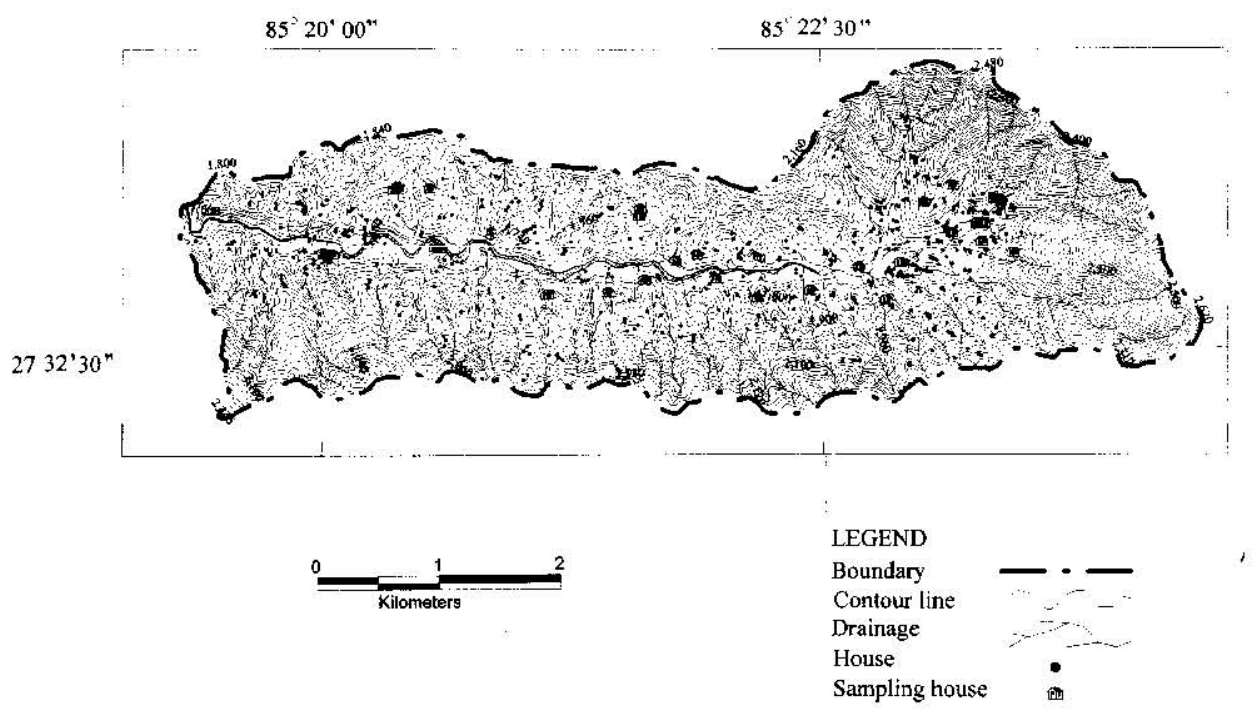

Fig. 1. Map of the study arca. 
Table 1. General and geomorphological characteristics of Nallu Khola Watershed.

\begin{tabular}{llc}
\hline Characteristics & Unit & \\
\hline Arca & $\left(\mathrm{km}^{2}\right)$ & 16.04 \\
Houses & $(\mathrm{No})$ & 509 \\
Population & $(\mathrm{No})$ & 4,000 (Approx.) \\
Population density & $\left(\mathrm{No} / \mathrm{km}^{2}\right)$ & 249.4 \\
Density of houses & $\left(\mathrm{No} / \mathrm{km}^{2}\right)$ & 31.7 \\
People per house & $\left(\mathrm{No} / \mathrm{No.}^{2}\right)$ & 7.9 \\
Land Use & $\left(\mathrm{km}^{2}\right)$ & $7.07(44 \%)$ \\
$\quad$ Cultivated Land & & $6.46(40 \%)$ \\
$\quad$ Forest & & $2.34(15 \%)$ \\
$\quad$ Shrub land & & $0.16(1 \%)$ \\
$\quad$ Other & $(\mathrm{m})$ & 2625 \\
$\quad$ Highest & & 1600 \\
$\quad$ Lowest & $(\mathrm{m})$ & 1025 \\
Relief & $(\mathrm{km})$ & 9.8 \\
Main Stream Length & $(\mathrm{degree})$ & 26 \\
Average Slope & $(\mathrm{km} / \mathrm{km})$ & 4.6 \\
Drainage Density & &
\end{tabular}

station in Godawari, which is about $5 \mathrm{~km}$ north from the study area (DPTC 1993).

The rocks of the Phulchauki group of Kathmandu complex (Chandragiri formation, Sopyang formation and Tistung Formation) underlie the Nallu Khola watershed (Stocklin and Bhattrai 1980). These formations consist mainly limestone quartzite, slates, phyllites, siltstone, sandstone and sandy limestone. The rocks are folded, faulted, fractured and highly weathered.

A big debris flow disaster occurred in Nallu Khola watershed on September 30, 1981. Because of heavy rain, many shallow landslides or slope failure occurred along each stream and gully in the upstrcam slopes and changed into debris flow when combined in the confluence. Due to this disaster 50 people were killed and many houses, roads, irrigation facilities, cultivated land and temples were damaged or destroyed (DPTC 1996).

\section{MATERIALS AND METHODS}

A varicty of techuiques and perspectives of data collection and analysis were used to approach a set of research questions and objectives. The study was accomplished in a series of phases from pre-field work to processing, analysis and integration of data. Secondary sources of information, such as published or printed materials and available documents, were reviewed before field investigation. A reconnaissance surveys was carried out before detail investigation of identifying geomorphological characteristics of the watershed and location of houses being studied. Primary data in the field were collected by means of observation, interviews and informal discussions with villagers. A total of 31 households ( $6.1 \%$ of total households) were sampled randomly for questionnaire survey. As shown in Figure 2, a set of questions were asked to the 


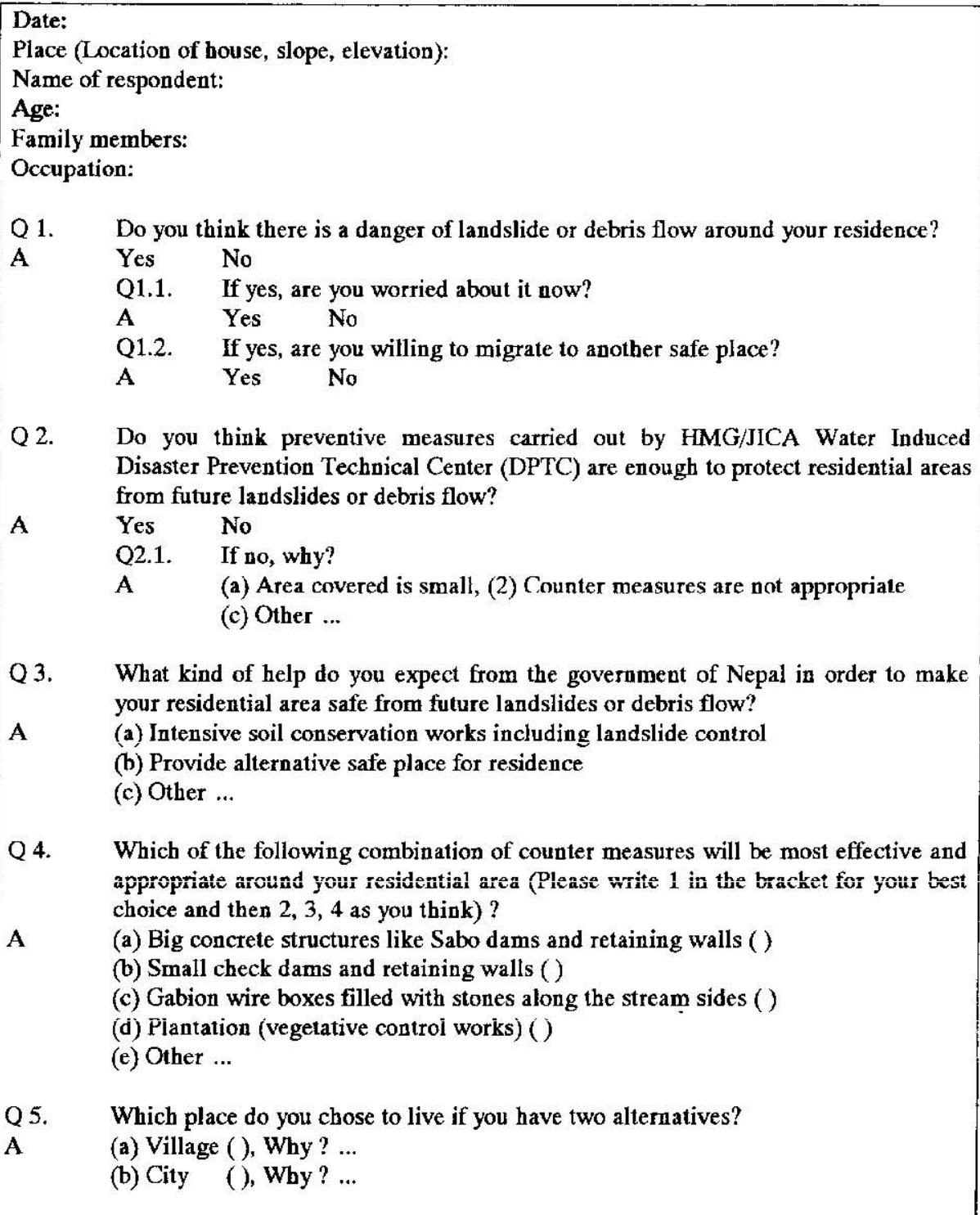

Fig. 2. A questionnaire used to study people's perception of landslide and debris flow hazard in Nallu Khola watersher, Nepal. 
respondents and filled on the spot. Important points raised during the informal discussion were also recorded. Field information such as locations of landslides and houses were marked on a topographic map of the area.

Stereo pairs of black and white aerial photographs were interpreted to plot landslides on the topographic map at a scale of 1:25,000 (HMG/Nepal 1994a and 1994b). Housc and landslide distribution maps of the study area were updated by combining data taken from the lield.

In order to carry out geomorphological analysis, contour lines, drainage network, location of landslides and houses were digitized using a software program called Mapinfo Professional from a scanned base map. Digitized map layers were superimposed. A net with unit cell size $0.5 \mathrm{~cm} \times 0.5 \mathrm{~cm}$ on the map, which is equivalent to $125 \mathrm{~m} \times 125 \mathrm{~m}$ in the field, was overlaid on all the map layers. Geomorphological analysis was carricd out using 1,135 cells over the entire study area. A slope map was derived from digitized contour map. Quantitative data of landslide, drainage, relief, slope gradients and houses were obtained for each cell. Slopes were grouped into following classes: up to $10^{\circ}, 11$ to $20^{\circ}$, 21 to $30^{\circ}, 31$ to $40^{\circ}, 41$ to $50^{\circ}$ and more than $50^{\circ}$. Area covered by each slope class was computed. Drainage frequency $f$, landslide density $d_{i}$ and density of houses $d_{t}$ in each slope class were estimated by applying the following equation

$$
f \text { or } d=\frac{\sum n}{\sum a}
$$

where $n$ is the number of drainage or landslide or house within a cell and $a$ is the area of the cell in the same class.

\section{RESULTS AND DISCUSSION}

Nallu Khola watershed is elongated in east-west direction and highly dissected by the drainage system from north, west. and south facing aspects. Average drainage density is estimated at $4.6 \mathrm{~km} / \mathrm{km}^{2}$. About 70 percent area has more than $20^{\circ}$ slope gradient. (Joshi 1999). There are a total of 509 houses, distributed from $1600 \mathrm{~m}$ to $2200 \mathrm{~m}$ elevation and 5 to $44^{\circ}$ slope gradient in Nallu Khola watershed (Figure 1). There are hamlets as well as scattered and isolated houses constructed in different locations such as gentiy sloping hili top, sloping ridge, sloping terrace, gently sloping terrace, stream side, debris deposited area and debris fan (Figure 3). A typical hamlet located between streamside and gently sloping terraces is shown in Pholo 1. Most of the houses are constructed on cut and filled base in the sloping land. Dwellers traditionally use locally available resources such as stone, slates, soil and wood to construct a typical two-story house of size about $30 \mathrm{~m}^{2}$. Reccntly, tiles or zine sheets are used as roofing materials. Clay soil is used as cementing material inside and out side of the walls. Doors, windows and bearns of the roofs are made of wood. Houses are painted with white or red color soils. There are small mines of white and red soils within the watershed. People have made holes by digging the soils in the mining area located in the foot part of the hill. This practice has initiates a huge landslide in one of the white soil (lime stone) area, due to toe cutting.

Density of houses in relation to slope gradient is shown in Figure 4. Density of houses is relatively lower in almost flat area because such areas are mostly along the streamsides 

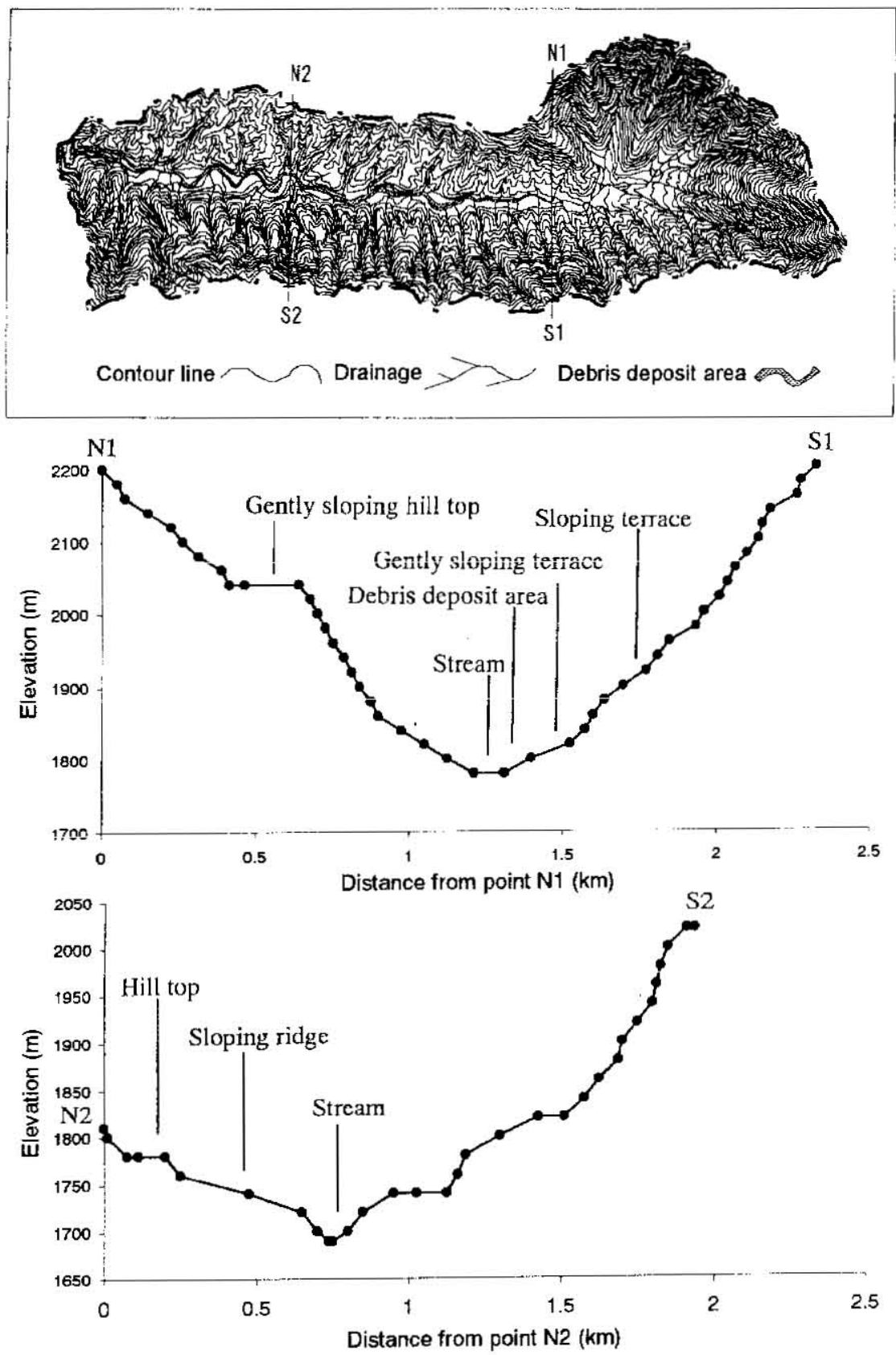

Fig. 3. Cross section along the line $\mathrm{N} 1-\mathrm{S} 1$ and N2--S2. 


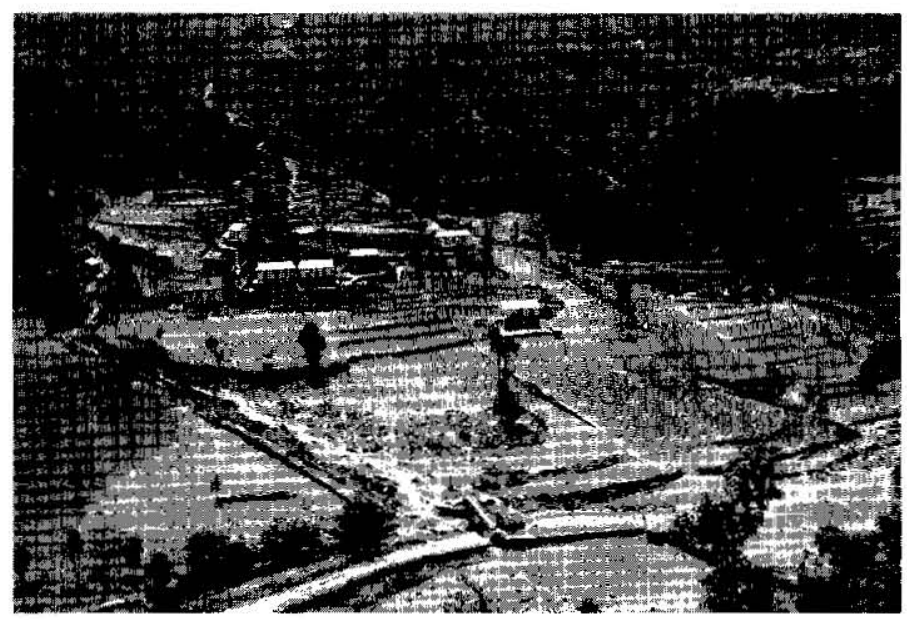

Photo. 1. $\Lambda$ typical residential area in Nallu Khola watershed.

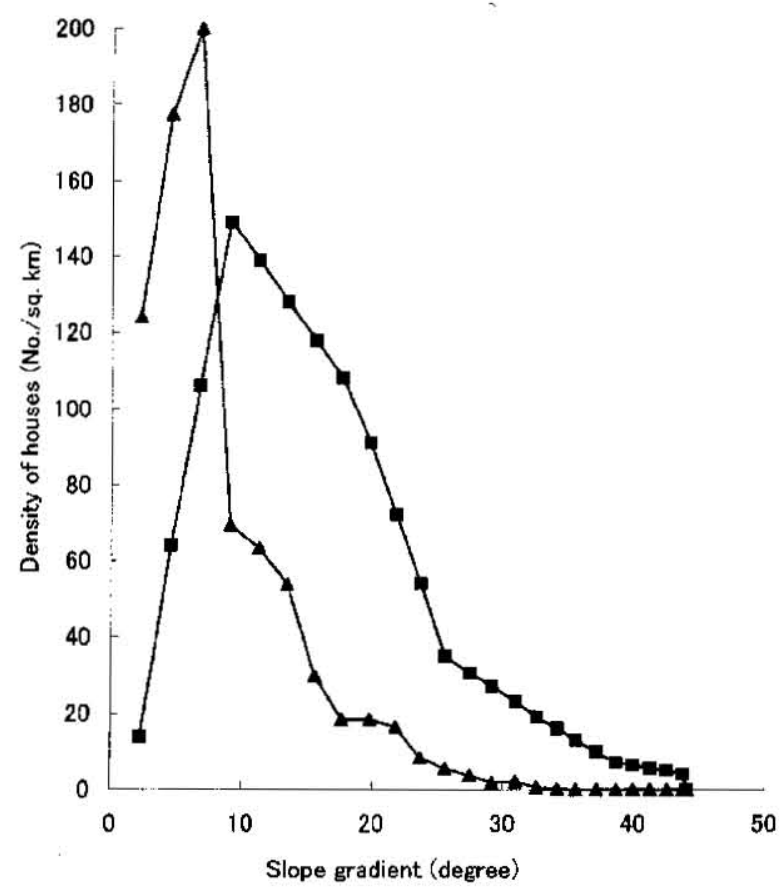

- Haruno-cho, Tenryu region, Japan

- Nallu Khola watershed, Nepal

Fig. 4. Relationship betwcen slope gradient and density of houses in IIaruno-cho, Terryu region, Japan and Nallu Khola watershed Nepal 
that have flooding or debris flow potentiality. Highest $d_{k}$ is around $10^{\circ}$ slope gradient, then decreases with the increase in slope gradient and becomes zero at $45^{\circ}$ in Nallu Khola watershed. Relationship between slope gradient and density of houses in Haruno-cho, Tenryu region of Japan shows the similar trend (Omura 1978). But, more houses arc distributed in steeper slopes in Nallu Khola watershed than Tenryu region. Figure 5 shows that $d_{i}$ is highest where relief is 20 melers. This is the same area, which has about $10^{n}$ slope gradient. Density of houses is highest where drainage frequency is zero and it decreases with increase in drainage frequency (Figure 6). It imtplics that people have a tendency to avoid gullied areas for residence as far as possible. Evidently, gullied areas are unstablc. Distribution of houses with respect to elevation shows that highest percentage of house is located between $1800-1900 \mathrm{~m}$ (Figure 7), but $d_{b}$ is highest between $1700-1800 \mathrm{~m}$ (Figure 8 ). This is mainly due to a link road, major part of which is constructed between $1700-1900 \mathrm{~m}$. Since accessibility below $1700 \mathrm{~m}$ and above $1900 \mathrm{~m}$ is difficult duc to lack of branch road, people have constructed many houses on both sides of link road for their convenience after its construction. From these relationships it can be inferred that the most preferred placc for residence in the study arca is a gently sloping land, having relief around $20 \mathrm{~m}$, clevation between $1700-1800 \mathrm{~m}$ and least dissected by the drainage which is stable and conveniert. Since, such stable as well as convenient areas are limited and population is ever increasing, people have constructed houscs in such places where slope gradient is up to $44^{\circ}$, relief is up to $120 \mathrm{~m}$ and drainage frequency is up to 4 (no./cell).

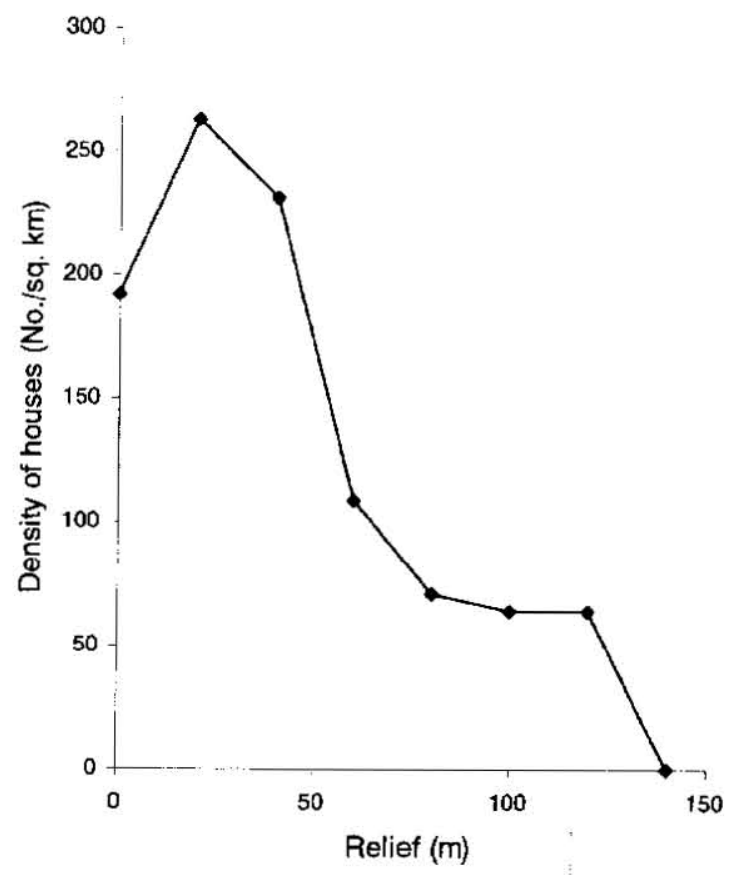

Fig. 5. Relationship betwecn rolief and density of houses in Nallı Khola watershed, Nepal. 


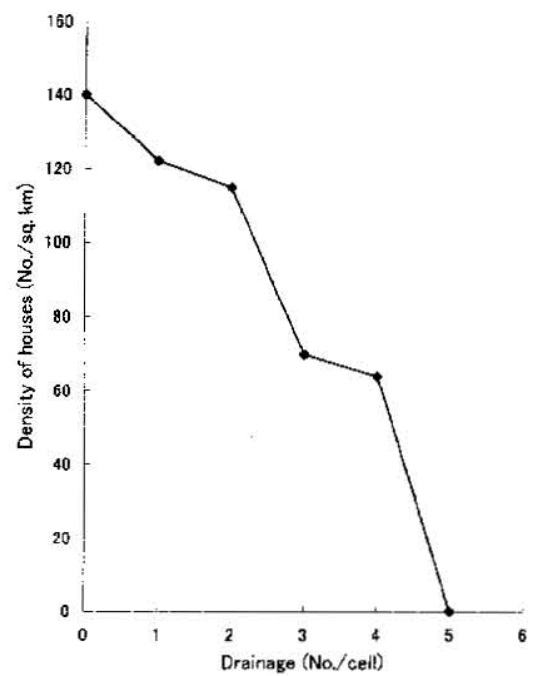

Fig. 6. Relationship between drainage frequency and density of houses in Nallu Khola watershed, Nepal.

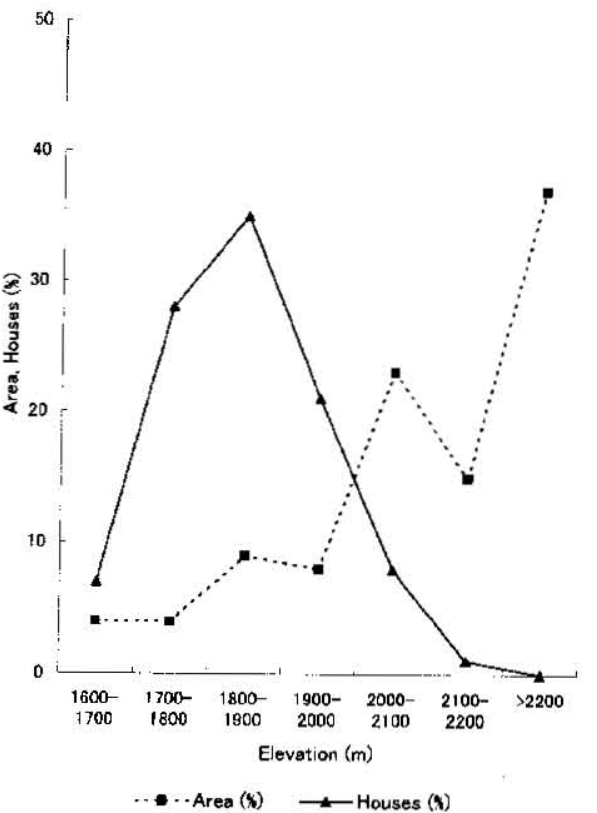

Fig. 7. Number of houses with respect to elevation in Nallu Khola watershed. 


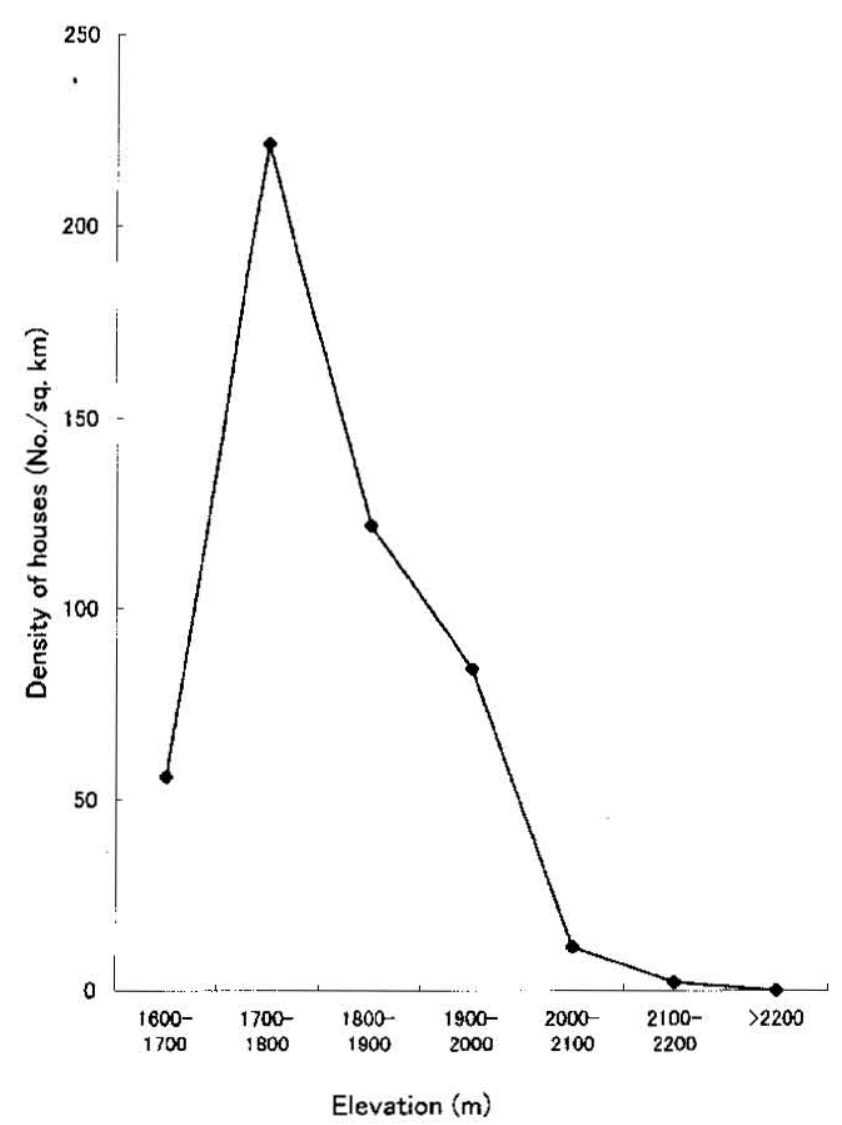

Fig. 8. Density of houses with respect to elevation in Nallu Khola watershed.

As shown in Figure 9, density of houses is highest where landslide density is lowest. It implies that majority of the people have avoided high landslide hazard areas for residence. However, there are some houses above $30^{\circ}$ slope gradient, which is either high landslide hazard area or steep rock slope. It has been reported that the natural hill slopes with gradient between $30^{\circ}$ and $40^{\circ}$ are found to be most, critical for failure in Nepal (Dikshit 1994, Joshi 1999). There are about $20 \%$ houses between $30^{\circ}$ and $40^{\circ}$ slope gradient, in Nallu Khola watershed. This is further supported by the landslide hazard map of the watershed, which shows $20 \%$ houses are constructed in dangerous locations that have been categorized as high hazard areas (Joshi, 1999). It means 101.8houses are located in unstable areas. If a landslide or debris flow hits one house, 7.9 people will have potentiality of darnage or may loose their life in an extreme case. In spite of such critical conditions, people are living there with their own perception of natural phenomena and 


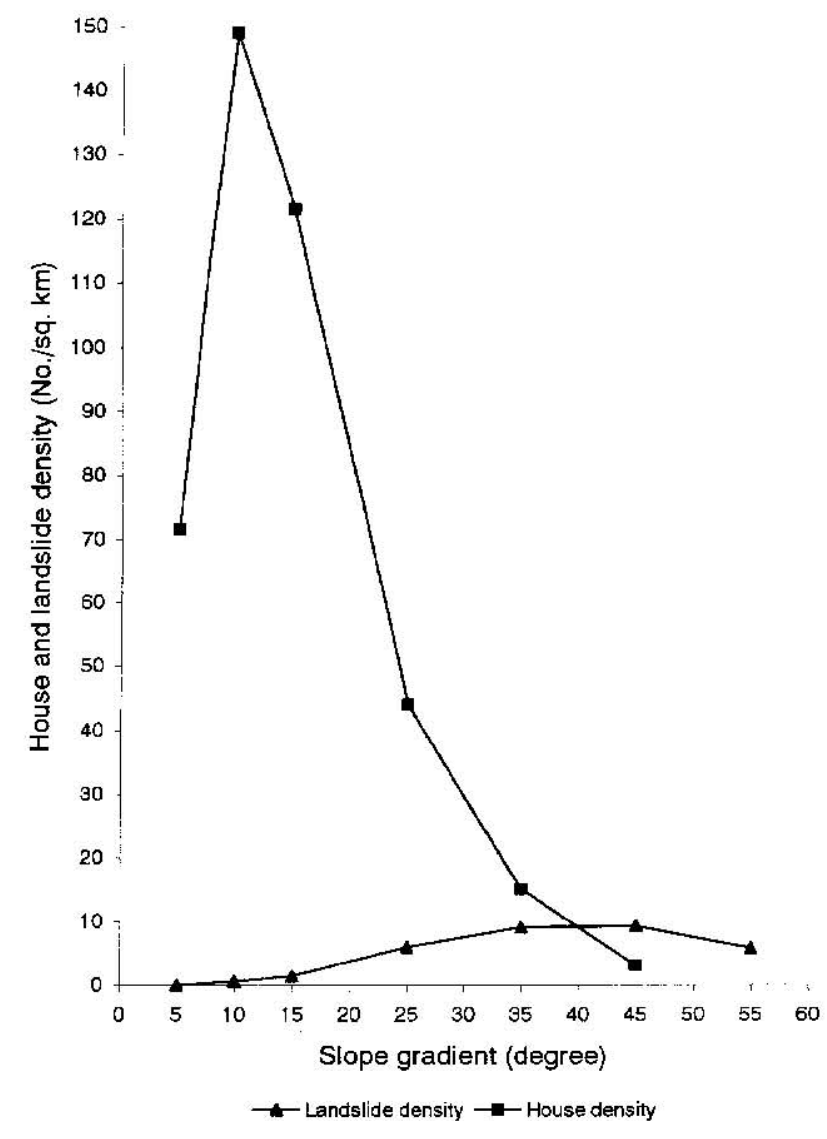

Fig. 9. Lensities of houses and landslides with respect to slope gradient in Nallu Khola watershed.

ethic for living.

An analysis of questionnaire survey shows that, $90.3 \%$ households are subsistence larmers. As shown in Table 2, 80.6\% inhabitants of Nallu Khola watershed think that there is a danger of landslide or debris flow around their residence. However, $54.8 \%$ households are worricd about the future landslide or debris now disaster. This suggests that majority of the people are aware of landslide hazard around their residence. Additional supporting fact is that $80 \%$ houses are built in low or medium landslide hazard area. But, only $12.9 \%$ households are willing to migrate if Government provide them alternative safo place for residence. It is mainly due to the poor socio-economic condition of the inhabitants, lack of alternative safe and convenient place in their vicinity, socio-psychological attachment to their birthplace and their traditional cultural background. 
Table 2. Response of the sampling households living in different localitics.

\begin{tabular}{|c|c|c|c|c|c|c|c|c|c|c|}
\hline \multirow{2}{*}{$\begin{array}{l}\text { Location of Sarmpling } \\
\text { Houses }\end{array}$} & & & \multicolumn{8}{|c|}{ Perception of households based on questionnaire survey } \\
\hline & \multicolumn{2}{|c|}{ Houses } & $\begin{array}{c}\mathrm{a} \\
\text { (No.) }\end{array}$ & $\begin{array}{c}\mathrm{b} \\
\text { (No.) }\end{array}$ & $\begin{array}{c}c \\
\text { (No.) }\end{array}$ & $\begin{array}{c}\mathrm{d} \\
\text { (No.) }\end{array}$ & $\begin{array}{c}\mathrm{c} \\
(\mathrm{No})\end{array}$ & $\begin{array}{c}f \\
\text { (No.) }\end{array}$ & $\begin{array}{c}g \\
\text { (No.) }\end{array}$ & $\begin{array}{c}\mathrm{h} \\
\text { (No.) }\end{array}$ \\
\hline Debris deposit area/fan & 4 & 12.9 & 4 & 4 & 2 & 2 & 2 & 4 & 0 & 0 \\
\hline Strearn side & 6 & 19.4 & 6 & 4 & 1 & 5 & 1 & 5 & 0 & 1 \\
\hline Sloping terrace & 7 & 22.6 & 7 & 7 & 1 & 7 & 0 & 6 & 0 & 1 \\
\hline Gently sloping terrace & 4 & 12.9 & 4 & 0 & 0 & 4 & 0 & 4 & 0 & 0 \\
\hline Sloping ridge & 5 & 16.1 & 4 & 2 & 0 & 5 & () & 4 & 1 & 0 \\
\hline Gently sloping hill top & 5 & 16.1 & 0 & 0 & 0 & 5 & 0 & 0 & 5 & 0 \\
\hline Whole watershed & 31 & 100.0 & 25 & 17 & 4 & 28 & 3 & 23 & 6 & 2 \\
\hline
\end{tabular}

a. Households aware about danger of landslide or debris flow around their residence

b. Households worried about future landslide or debris flow disaster around their residence

c. Households willing to migrate in another place

d. Households expecting intensive soil conscrvation works from the Gowernment of Nepal

c. Households expecting alternative safe place for rosidence from the Government of veyal

f. Households who think (1) Gahion wire filled with big stones along the stream sides, (2) Sinall check-damis in gullies and (3) Plantation in the bare land or degraded forest, are the most appropriate and effective countermeasures for landslides and debris flow

g. Households who thirk (1) Plantation in the bare land or degraded forest, (2) Small check-..tunus in gullies and (3) Gabion wirc filled with big stones along the stream sides, are the nost appropriatc and effective countermeasures for landslides and debris flow

h. Householks who think (1) Big concrete structures, (2) Gabion wire filled with big stones along thc stream sides, and (3) Small check-dams in gullies, are the most appropriate and effective countermeasures for landslides and debris flow

Table 3. People's priority for living in village and cily.

\begin{tabular}{|c|c|c|c|}
\hline \multirow[t]{2}{*}{ Respondents'Age } & \multicolumn{2}{|c|}{ Priority for living (\%) } & \multirow[t]{2}{*}{ Total $(\%)$} \\
\hline & Village & City & \\
\hline Below 30 years & $3(9.68)$ & $6(19.35)$ & $9(29.03)$ \\
\hline 30 years and above & $22(70.79)$ & $0(0)$ & $22(70.79)$ \\
\hline Total & $25(80.65)$ & $6(19.35)$ & $31(100)$ \\
\hline
\end{tabular}

Regarding the expectations from Government of Nepal. $90.3 \%$ people gave priority to intensive soil conservation works including landslide control works. All the people opincd that disaster prevention measures so far carricd out in Nallu Khola are not enough because arca covered is small. Water Induced Disaster Prevention Technical Centre (DPTC) of Nepal established with the help of Japan International Cooperation Agency (JICA) selected Nallu Khola watershed as a model site for debris flow disaster prevention works. DPTC has constructed some retaining walls and a series of check dams in two gullies where debris flow occurred in 1981 . Based on their experience, $74.2 \%$ people have given the priority to gabion wire filled with large stone along the stream sides, small 
check dams in the gullies and plantation in all the bare land and degraded forest patches as the most appropriate and effective counter measure against landslide and debris flow disaster.

An analysis of inhabitants' priority for living shows that $80.6 \%$ people prefer to live in their own village (Table 3). All the people above 30 years age expressed their desire to live in village, because natural environment is clean, social environment is friendly and peaceful though life is hard. Moreover, they feel close affiliation with their birthplace. Among the young people below 30 years age, $75 \%$ answered that they prefer to live in city, since there are opportunities for employment and facilities to live comfortable life.

\section{CONCLUSION}

The natural hill slopes with gradient about $10^{\circ}$, relief around $20 \mathrm{~m}$ elevation between $1700-1800 \mathrm{~m}$, least dissected by the drainage and lowest landslide potentiality are the most preferred places for residence in Nallu Khola watershed. Such areas are most convenient and safe for residence. Majority of the inhabitants are aware of landslides hazard but they are not ready to migrate out side due to the poor socio-economic condition, lack of alternative safe and convenient place in their vicinity, socio-psychological attachment to their birthplace and their traditional cultural background. Majority of the inhabitants secks for intensive soil conservation works including landslide control measures from the Government of Nepal. Hence, it can be concluded that a study of relationship among geomorphological characteristics of a watershed, distribution of dwellers' houses and peoples' perception regarding landslide hazard around their residence will be of use as a guide to prepare sediment disaster prevention plans and to find out safe place for residence in the mountains.

\section{REFERENCES}

Daluwatta. D., S. Deraniyagala and H. M. R. Menike 1994 Mapping of Human Settlements and Infrastructures for P'reliminary Assessment of Risks due to Landslides. Published in "Landslides in Sri Lanka". National Building Research Organization, Publications (199i-1994). pp. 159

Dikshit, A. M. 1994 Landslide Hazards in Nepal: Causes and Assessment. Water Nepal, Vol. 2, pp. 2-12

DE']C, 1993 Review of 1981 flood/debris flow in Nallikhola basin in central Nepal. HMG/JICA Water Induced Disaster Prevention Technicat Center (DT'TC), Ministry of Water Resources, Kathmandu

DPTC, 1996 Final report on survey of Nallu Khola Vol. I. HMG/JICA Water Induced Disaster Prevention Techuical Center (DPTO), Ministry of Water Resources, Kathmandu

IIMGiNepal, 1994a Topographic Map of Tikabhairab Area. S. No. 278506C His Majesty's Government of Nepal, Department of Survey, Kathmandu

HMC/Nepal, 1994b Topographic Map of Phulchoki Area. S. No. 278506D His Majesty's Grovernmernt of Nepal, Department of Survey: Kathmandu

Joshi, J. 19999 Landslide Hazard Mapping to Mitigate Sediment Jisaster in Nallu Khola watershed. Nepal. M Sc: Thesis. Department of Forestry, Faculty of Agriculture, Kyushu University, Fukuoka, Japan

MOH, 1994 Disaster of July 1993 in Nepal. Ministry of Honc, IIMG/Niepal in cooperation with Water Inducer Disaster l'revention T'echnical Center (DPTC), Kathmandu, Nepal

Omura, H. 1978 Distribution of houses in Haruno-cho, Japan. Unpublished

Sharma, C. K. 1988 Natural Hazards and Man Madc Impacts in the Nepal Himalaya. Kathmandu

Stocklin, J. and K. I. I3hattarai 1980 Geological Map of Kathmarldu Area arıd Central Mahabharat Range. UNTP and De:partment of Mines and Gcology, His Majesty's Goverment of Nepal, Kathmandu 